\title{
DELINIASI ENDAPAN TIMAH BERDASARKAN ANALISIS ANOMALI GAYABERAT DI DAERAH BANGKA SELATAN
}

\author{
Oleh: \\ Tatang Padmawidjaja \\ Pusat Survei Geologi, Badan Geologi \\ Jalan Diponegoro No 57 Bandung
}

\section{SARI}

Analisis data gayaberat untuk deliniasi endapan timah yang tersebar di Bangka Selatan telah dilakukan secara kualitatif dan kuantitatif. Anomali gayaberat di daerah Bangka Selatan berkisar antara 17 sampai 46 mgal, dengan anomali gayaberat residual antara $-8,5$ mgal sampai 5,0 mgal. Anomali gayaberat dikelompokan menjadi dua kelompok yaitu kelompok anomali rendah dan kelompok anomali tinggi sedangkan anomali gayaberat residual dibedakan menjadi anomali positif dan anomali negatif.

Analisis kuantitatif dalam pemodelan geologi pada penampang anomali gayaberat residual menghasilkan lapisan batuan dengan rapat massa 2,69 gr/cc yang dapat ditafsirkan sebagai Batuan Komplek Pemali (CpP).

Komplek Pemali merupakan batuan yang mendasari daerah tersebut. Komplek Pemali ini diterobos oleh batuan dengan rapat massa 2,58 gr/cc yang ditafsirkan sebagai batuan terobosan granit $\left(\mathrm{T}_{\mathrm{R}} \mathrm{Jkg}\right)$. Penerobosan ini diperkirakan melalui bidang lemah pada batuan Komplek Pemali yang ditafsirkan sebagai bidang sesar.

Oleh karena itu kontak antara batuan Komplek Pemali, Formasi Tanjunggenting $\left(T_{R} t\right)$ dengan batuan terobosan granit diperkirakan sebagai kontak sesar, yang diduga sebagai kontak yang berpotensi untuk keterdapatan endapan timah di daerah Bangka Selatan.

Kata kunci : Anomali sisa, Bangka, endapan timah, gaya berat, rapat massa.

\section{ABSTRACT}

Analysis of the gravity data for delineation of tin deposits scattered South Bangka has been done qualitatively and quantitatively. Gravity anomaly in South Bangka ranged between 17 to $46 \mathrm{mgal}$, with the residual gravity anomaly between -8.5 to $5.0 \mathrm{mgal}$. Gravity anomaly is classified into two groups namely low and high anomaly, while residual gravity is differentiated into positive and negative anomalies.

Quantitative analysis of the geological modeling in cross section of residual gravity anomaly obtained rock layer with density of $2.69 \mathrm{~g} / \mathrm{cc}$ which can be interpreted as Pemali Complex $\left(C_{P} P\right)$.

The Pemali Complex is basement in this area, which is intruded by rocks with density $2.58 \mathrm{~g} / \mathrm{cc}$ which is interpreted as granite intrussion $\left(T_{R} \mathrm{Jkg}\right)$. This intrussion appears to the surface through the weak zone in the Pemali Complex, which can be interpreted as fault zone.

Therefore the contact between Pemali Complex and Tanjunggenting Formation $\left(T_{R} T\right)$ with granite intrusion can be interpreted as the fault contact, which is suspected as potential area for tin deposits in South Bangka.

Keyword: Residual anomaly, Bangka, tin deposit, gravity, density. 


\section{PENDAHULUAN}

Analisis anomali gaya berat daerah Bangka Selatan ini merupakan lanjutan dari analisis gaya berat lembar Bangka Utara yang telah dipublikasikan sebelumnya (Simamora, W.H., 2007). Sehingga analisis ini dapat mengungkapkan struktur bawah permukaan di daerah bagian selatan Pulau Bangka. Disamping itu, bagaimana hubungannya antara struktur bawah permukaan Bangka Utara dan Bangka Selatan. Dengan demikian dapat diketahui kaitannya antara endapan bijih timah dengan batuan yang terdapat di daerah Pulau Bangka secara keseluruhan.

Analisis yang di sajikan dalam tulisan ini merupakan analisis tahap lanjut, hasil pemetaan gaya berat lembar Bangka Selatan, skala 1 : 250.000 (Marzuki drr., 1990), dengan lokasi terletak pada koordinat $105^{\circ} 45^{\prime} \mathrm{BT}-107^{\circ} 00^{\prime} \mathrm{BT}$ dan $2^{\circ} 20^{\prime} \mathrm{LS}-3^{\circ} 15^{\prime}$ LS (Gambar 1).

Tujuan makalah ini untuk mengkaji lebih rinci hubungan antara anomali gaya berat dengan struktur geologi permukaan serta aspeknya terhadap endapan timah di daerah Bangka Selatan.

\section{METODOLOGI}

Metodologi dalam penelitian adalah melakukan analisis dari laporan-laporan yang telah dipublikasi, yaitu analisis gayaberat daerah Bangka Selatan dalam penafsiran struktur geologi yang berhubungan dengan keterdapatan potensi timah. Untuk memperoleh gambaran struktur geologi dangkal dilakukan pemisahan anomali gayaberat yang pemodelan geologi untuk menentukan kontak struktur sebagai daerah endapan timah. Dalam pemodelan geologi bawah permukaan yang berhubungan potensi endapan timah dengan Software Gravmag yang dilakukan pada penampang anomali residual.

\section{TINJAUAN GEOLOGI}

Menurut Hutchison (1980), rekonstruksi tektonik regional Pra-Tersier Asia Tenggara yang terdiri dari Semenanjung Malaya dan Sumatera, dibagi menjadi tiga mintakat yaitu: Mintakat Sumatera Barat (Cathaysia), Sinoburmalaya (Gondwana) dan Malaya Timur (Cataysia) (Gambar 2). Daerah penelitian termasuk ke

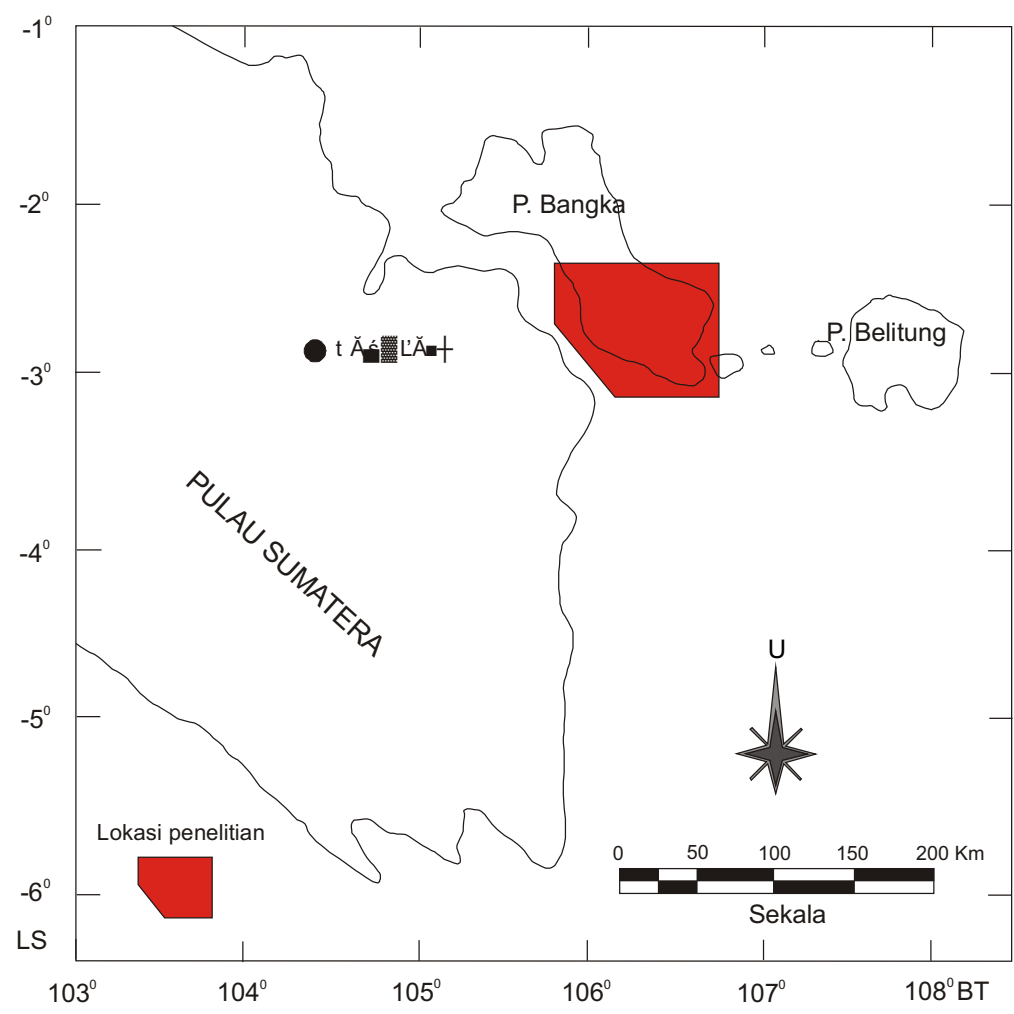

Gambar 1. Peta Indek Lokasi Penelitian Gayaberat 
dalam Mintakat Malaya Timur dan ditandai oleh kehadiran batugamping fusulinid Perem Bawah serta batuan gunung api Perem Akhir.

Pulau Bangka terdiri dari batuan metasedimen berumur Trias Atas, dengan pelamparan dari utara sampai selatan dan diterobos oleh batuan granit berumur post Trias (Djumhana, 1995). Menurut Gafoer drr. (1992), tataan geologi regional Pulau Bangka merupakan bagian luar cekungan busur belakang Sumatera dan termasuk kedalam Kerak Benua.

Daerah Bangka Selatan merupakan daerah busur kepulauan pada Zaman Trias (Katili, 1973). Tetapi menurut Lehman (1990), daerah ini termasuk ke dalam bagian sabuk timah Asia Tenggara yang memanjang dari Burma, Thailand, Semenanjung Malaya dan termasuk Bangka, Belitung dan pulau-pulau kecil lainnya.

Geologi Bangka Selatan pada dasarnya sama dengan geologi Bangka Utara (Gambar 3). Batuan tertua berupa Komplek Malihan Pemali (CPp) yang terdapat di bagian Bangka Utara (Mangga dan Jamal, 1994), berumur Permo-Karbon, terdiri atas batuan malihan berupa sekis, filit dan kuarsit. Filit berwarna kelabu kecoklatan, struktur mendaun dan berurat kuarsa. Sekis, kelabu kehijauan, struktur mendaun, terkekarkan, setempat rekahannya terisi kuarsa atau oksida besi sedangkan kuarsit berwarna putih kotor, kecoklatan, keras tersusun oleh kuarsa dan feldspar. Komplek Pemali ditindih secara tidak selaras oleh Formasi Tanjunggenting $\left(T_{R} t\right)$, berumur Trias, tersusun oleh perselingan batulempung, batupasir dan batupasir meta. Batuan Tersier yang dijumpai di daerah penelitian berupa Formasi Ranggam ( $T Q r$ ), terdiri dari perselingan batupasir, batulempung tufaan dengan sisipan batulanau dan bahan organik. Batuan terobosan yang dijumpai di daerah Bangka Selatan berupa Granit Klabat $\left(T_{R} \mathrm{Jkg}\right)$, terdiri dari granit biotit, granodiorit, granit genesan. Granit biotit berwarna kelabu, tekstur porfiritik dengan butiran kristal berukuran sedang-kasar. Granodiorit berwarna putik kotor, berbintik hitam. Granit genesan berwarna kelabu dan berstruktur perdaunan. Umur satuan granit adalah Trias-Jura Awal (Graha, 1990). Granit Klabat ini menerobos Formasi Tanjung Genting dan Komplek Malihan Pemali.

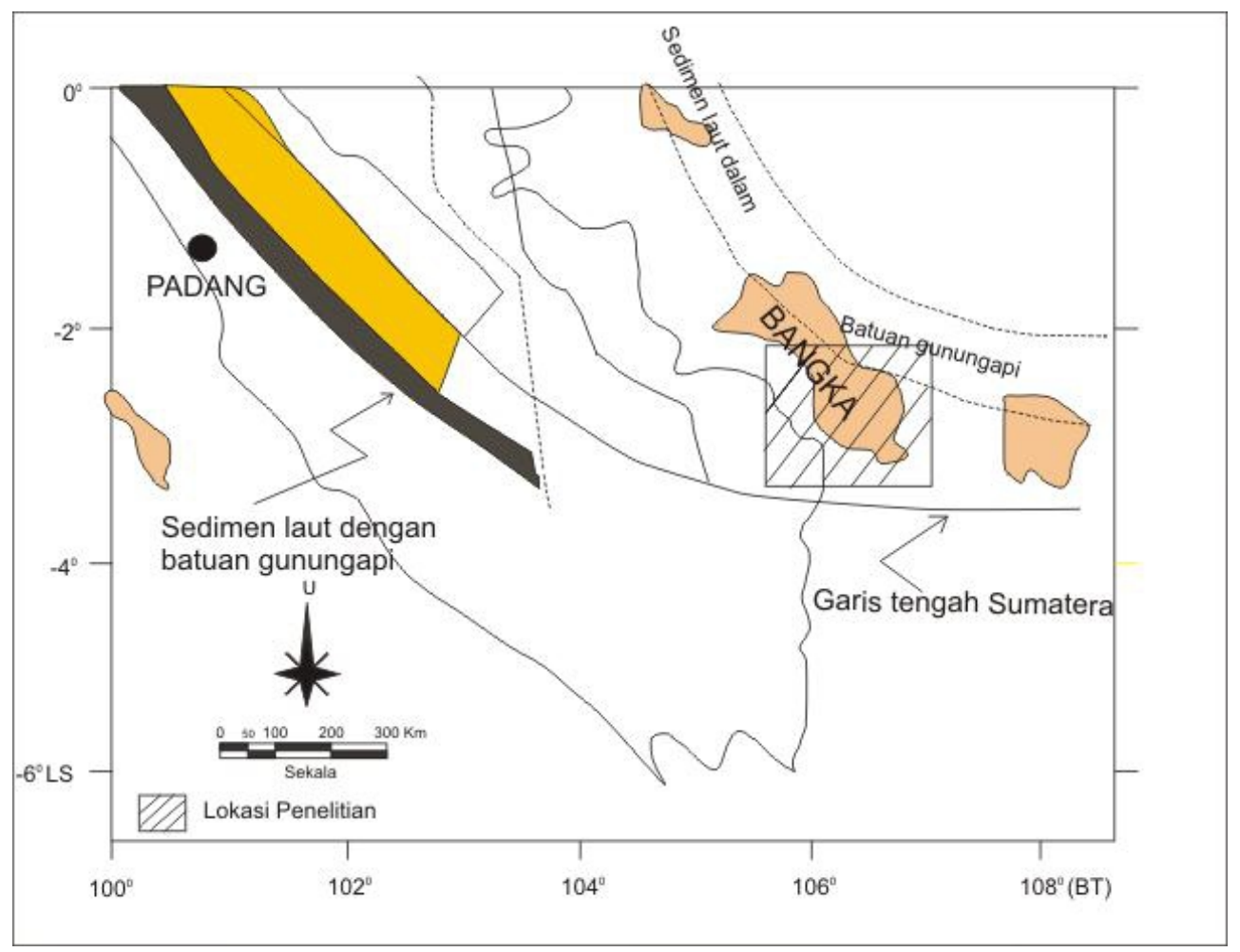

Gambar 2. Sebaran batuan Pra-Tertier di Sumatera (Hutchison, 1980). 


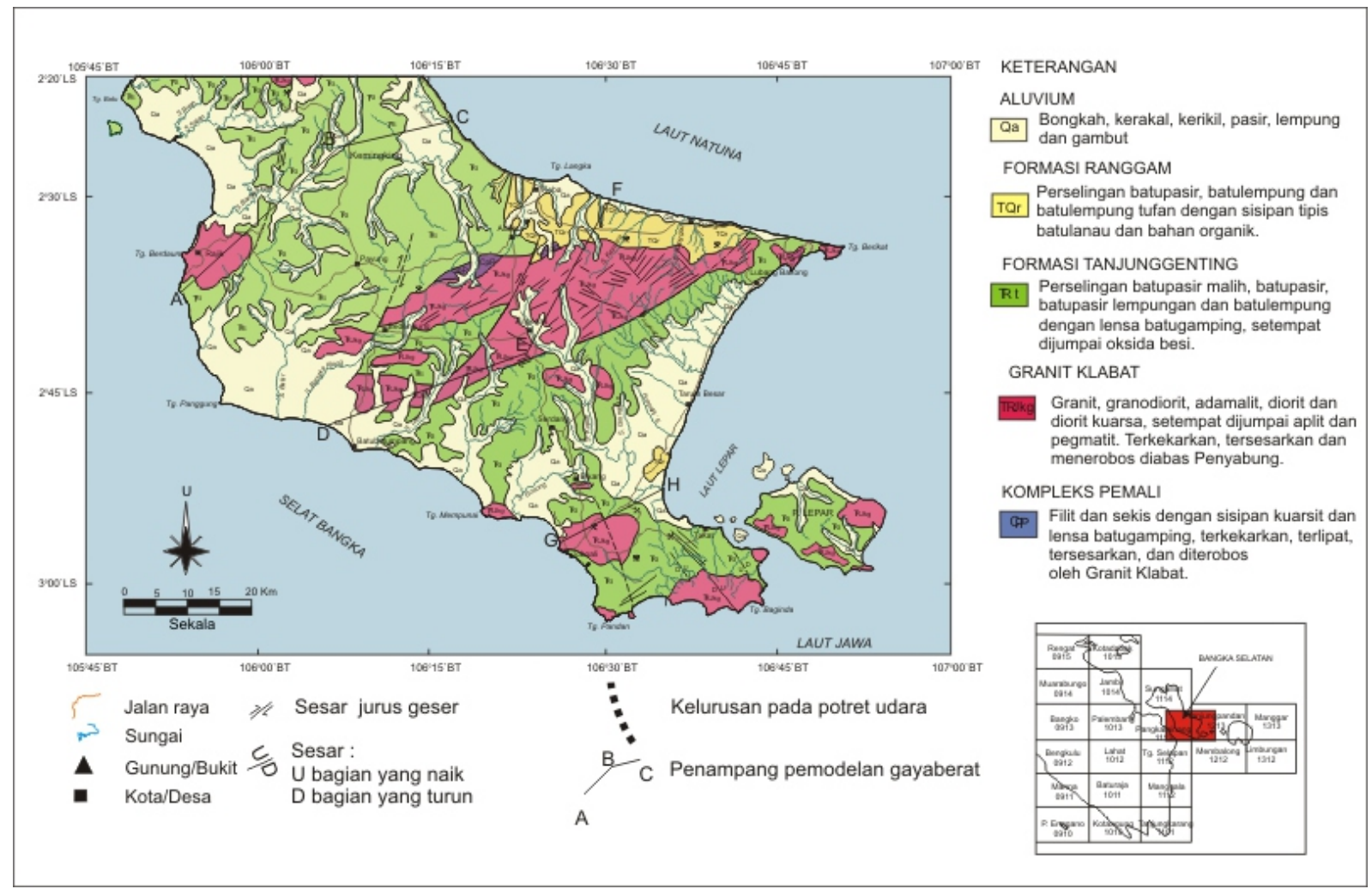

Gambar 3. Peta geologi Bangka Selatan, yang disederhanakan (Margono drr, 1995).

Berdasarkan jenisnya, batuan granitik di pulau Bangka dapat digolongkan ke dalam 2 tipe yaitu tipe batuan beku (Igneous type) dan tipe batuan sedimen (Sedimentary type) (Chappel \& White, 1974) sedangkan Ishihara (1977) membagi dalam seri ilmenit dan seri magnetik. Djumhana (1995) mengelompokkan batuan granitik di daerah Bangka Selatan berdasarkan penyebarannya berupa Plutonik Permis, Plutonik Koba, Plutonik Buluh atau Pading, Plutonik S. Ulim, Plutonik S. Kepoh, Plutonik S. Basong, Granitik Toboali, Plutonik Namak, Plutonik Batu Long dan Plotonik Lepar. Batuan Kuarter ditemukan berupa lumpur, kerakal, kerikil, lempung yang terdapat sebagai endapan sungai, rawa dan pantai berupa Aluvium (Qa). Lumpur, lanau dan pasir yang berupa Endapan Rawa (Qs) dan Pasir Kuarsa (Qak) (Gambar 4).

Struktur yang terdapat di daerah Bangka Selatan berupa kelurusan, lipatan dan sesar. Kelurusan terutama pada granit dengan arah yang beragam. Lipatan terdapat pada satuan batupasir dan batulempung Formasi Tanjunggenting dan Formasi Ranggam. Sedangkan sesar yang berkembang di daerah ini berupa sesar mendatar dan sesar normal. Sesar mendatar berarah timur laut-barat daya, sesar normal berarah barat laut-tenggara. Batuan ini menerobos batuan Komplek Malihan Pemali yang diperkirakan sebagai batuan dasar di daerah tersebut, yang membentuk kontak struktur, pada lapisan kontak struktur membentuk sedimen hasil rombakan dan pelapukan. Perombakan dan pelapukan batuan granit akan lebih efektip terjadi di alam apabila ditunjang oleh adanya pengaruh struktur sesar atau kekar di daerah tersebut. Seperti diketahui bahwa Pulau Bangka pada umumnya merupakan penghasil timah yang ditemukan dalam jebakan-jebakan endapan eluvial yang terendapkan di aliran sungai purba (Paleochannel). Endapan timah merupakan hasil pelapukan rombakan yang terjebak di daerah sedimen berasal dari hasil pelapukan rombakan batuan granit yang telah mengalami proses kimiawi sehingga terjadi pengkonsentrasian bijih-bijih timah dan terendapkan dalam aliran-aliran sungai purba. 


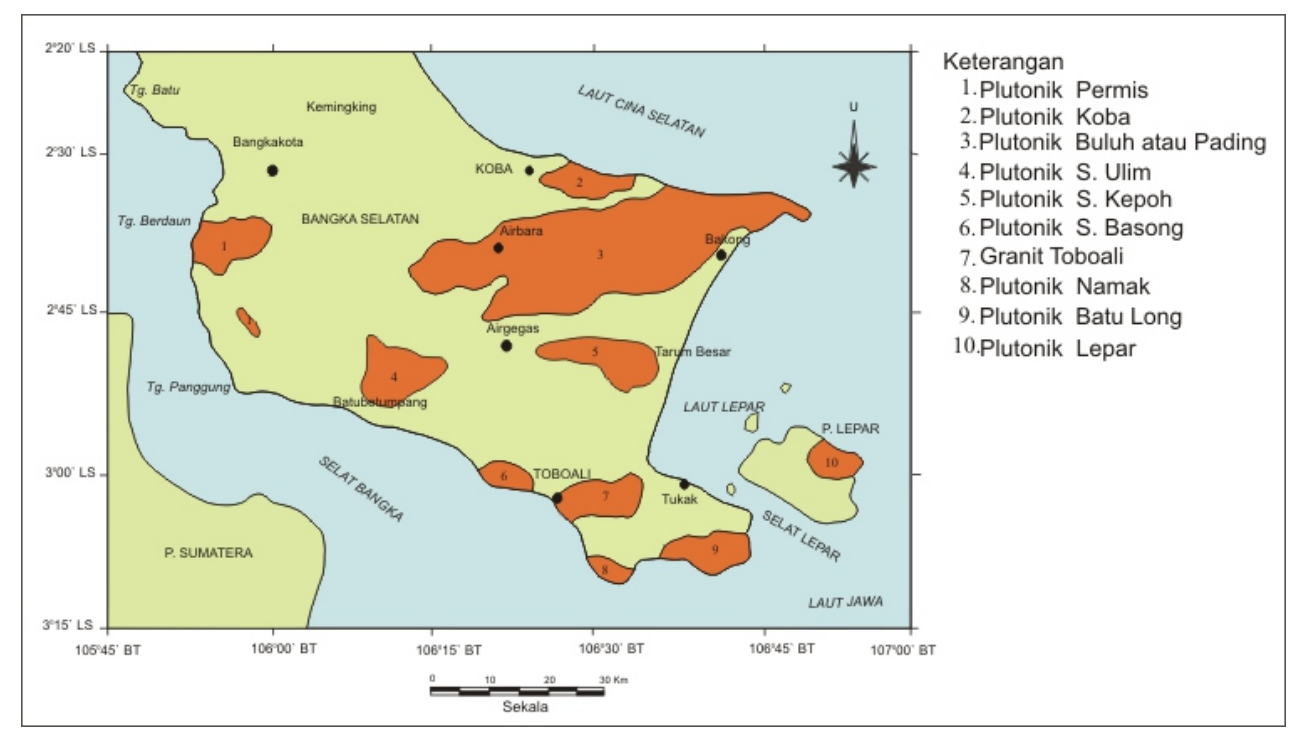

Gambar 4. Penyebaran batuan granitik di Bangka selatan (Djumhana 1995).

\section{HASIL PENELITIAN DAN ANALISIS}

Data gaya berat diperoleh dari hasil pengukuran pada titik pengamatan di daerah penelitian (Gambar 5). Selanjutnya data ini di proses menjadi peta anomali gaya berat dan telah dipublikasikan dalam bentuk Peta Anomali Bouguer Lembar Bangka Selatan, Skala 1:250.000 oleh Marzuki drr. (1995).

Anomali Bouguer hasil perhitungan, merupakan gabungan medan gaya berat yang diakibatkan oleh gabungan pengaruh struktur dangkal dan struktur dalam. Sehingga kadang-kadang anomali pengaruh tubuh massa batuan lokal, yang justru menarik secara eksplorasi menjadi sering tersamarkan. Oleh karena itu dilakukan pemisahan pengaruh regional terhadap anomali Bouguer dengan cara surface fitting. Pemisahan dilakukan dengan pendekatan least square (kwadrat terkecil) untuk mendapatkan pontential surface yang mendekati nilai gaya berat pengamatan. Pemisahan ini menghasil nilai anomali sisa, selanjutnya dilakukan pengkonturan yang dapat dilihat pada Gambar 6 .

\section{PEMBAHASAN}

Proses pengolahan data seperti dijelaskan di atas, menghasilkan nilai gaya berat yang disajikan dalam bentuk peta anomali gaya berat (Bouguer) dan peta anomali sisa (Gambar 5 dan 6).

Masing-masing peta ini memberikan ciri khas dalam kaitannya dengan kandungan informasi, guna penafsiran aspek kebumiannya.

\section{Anomali Bouguer}

Nilai anomali Bouguer berkisar antara 17,0 - 46,0 mgal dengan selang kontur 1,0 mgal, dibedakan menjadi anomali rendah dan anomali tinggi (Gambar 6). Anomali rendah, dengan nilai $<30,0$ mgal digambarkan berwarna kuning sampai merah, dengan pelamparan di beberapa tempat, yaitu di pantai timur Desa Lubang Bakong dan Desa Rangau yang menerus kearah barat, Desa Airbara, Air Gegas sampai Desa Payung dan Desa Badenguna, berbelok kearah barat daya dan berakhir di sebelah timur laut Desa Batubetumpang. Anomali ini dijumpai pula di sebelah timur Kota Toboali dengan pelamparan sepanjang pantai Tanjung Pandan sampai Desa Tukak dan Tanjung Baginda. Anomali rendah dijumpai pula di daerah pantai barat yaitu di daerah Tanjung Berdaun. Di bagian utara (batas peta), anomali rendah ini dijumpai pula dan diperkirakan merupakan kelompok anomali rendah daerah Gunung Mangkol (Simamora, 2007). Pada peta geologi (Gambar 3), anomali rendah ini di dominasi oleh batuan terobosan Granit Klabat (TRJkg). Dari kenyataan ini, anomali Bouguer rendah yang terdapat di daerah Bangka Selatan ini dapat diartikan sebagai pengaruh dominasi medan gaya berat batuan terobosan Granit Klabat seperti yang terdapat di daerah Bangka Utara (Simamora, 2007). Pada peta geologi 
(Gambar 3), di daerah Tanjung Mempunai dijumpai pula batuan terobosan Granit Klabat (Plutonik S. Basong, Djumhana 1995), tetapi nilai anomali rendah tidak tercermin di daerah tersebut justru anomali cenderung tinggi, kemungkinan Granit Klabat yang terdapat di daerah tersebut tidak sama dengan batuan terobosan yang terdapat di tempat lain di daerah tersebut.

Anomali tinggi, dengan nilai $>30,0$ mgal digambarkan berwarna hijau. Anomali ini di jumpai di bagian selatan, barat dan utara daerah penelitian (Gambar 6).

Di bagian selatan, pelamparannya dimulai dari pantai Desa Tarum Besar dan pantai sebelah utara Desa Tukat, terus ke arah barat, melintasi Desa Bikang, Desa Serdang sampai pantai Tanjung Mempanai. Membentuk tinggian anomali dengan puncak tinggian di sekitar Tanjung Mempanai dan Desa Bikang, dengan sumbu berarah hampir barat timur. Anomali ini berlanjut ke arah pantai barat, melalui Desa Batubetumpang dan Desa Rajik melintasi Tanjung Panggung. Di sebelah timur Desa Rajik anomali berbelok kearah utara melewati Desa Payung dan melebar ke arah timur dan barat. Anomali ini membentuk tinggian anomali dengan bersumbu barat laut-tenggara dengan puncak tinggian mencapai 46,0 mgal di dekat Desa Kemingking. Di permukaan, pelamparan anomali tinggi ini didominasi oleh batuan
Formasi Tanjung Genting $\left(\mathrm{T}_{\mathrm{R}} \mathrm{t}\right)$ yang terdiri dari perselingan batupasir malih, batupasir, batupasir lempungan dan batulempung, Formasi Ranggam (TQr) terdiri dari perselingan batupasir, batulempung, batutufaan dengan sisipan tipis batulanau bahan organik dan Aluvium (Qa).

Anomali dengan nilai tinggi yang mendominasi penyebaran Formasi Ranggam dan Formasi Tanjunggenting diperkirakan tidak hanya pengaruh dari medan gaya berat kedua Formasi tersebut tetapi juga dipengaruhi oleh batuan dengan rapat massa yang lebih tinggi yang mengalasi kedua formasi tersebut. Diperkirakan batuan tersebut adalah batuan Komlek Malihan Pemali (CpP). Hal ini dibuktikan oleh adanya singkapan batuan tersebut di sebelah tenggara dan barat daya DesaAirbara (Gambar 3).

Di sebelah timur Desa Air Bara dan Airgegas terjadi pembelokan kontur anomali yang cukup tajam pada anomali rendah berarah hampir barat laut-tenggara sehingga seolah olah terbentuk dua cekungan anomali rendah di daerah ini. Pembelokan anomali ini diperkirakan akibat adanya sesar dexstral pada batuan terobosan Granit Klabat. Hal ini diduga sebagai pemicu terjadinya sesar-sesar pada batuan granit di daerah tersebut (Margono drr. 1995).

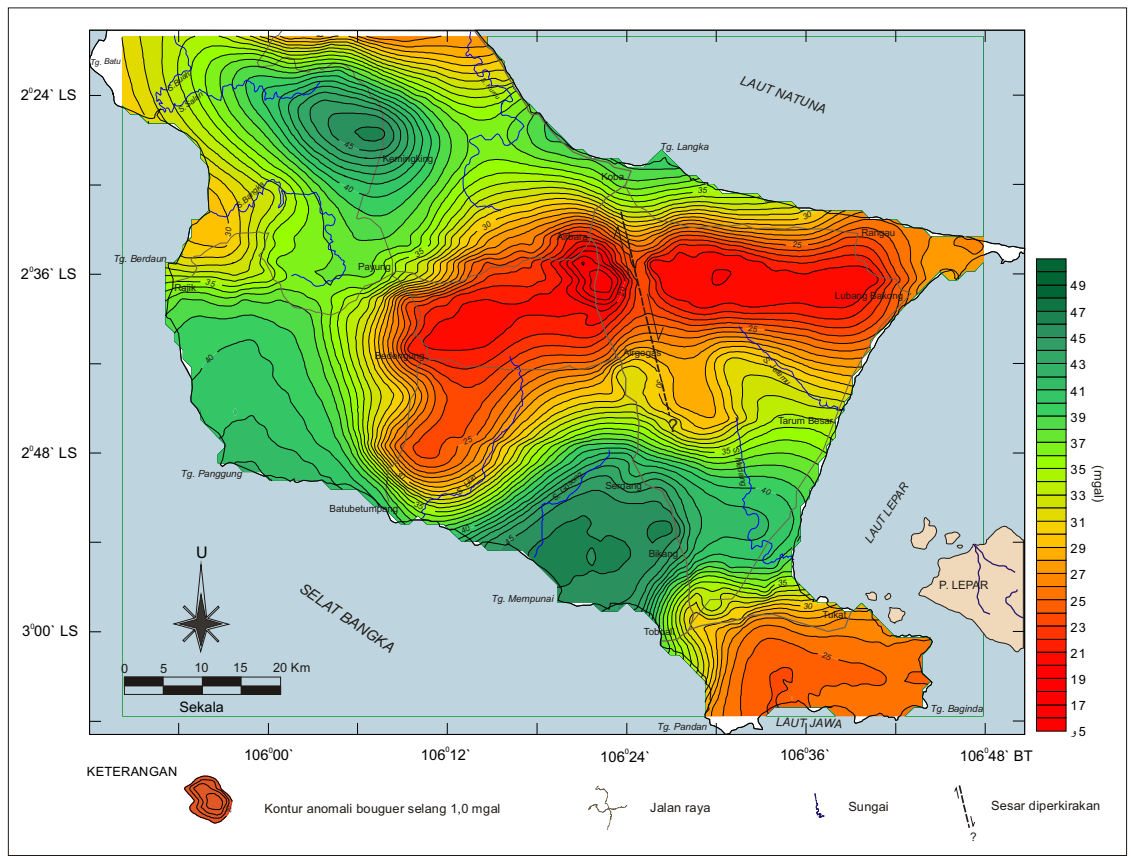

Gambar 5. Peta kontur anomali gayaberat daerah Bangka Selatan ( Marzuki, drr, 1990). 


\section{Anomali Gayaberat Residual}

Anomali gayaberat residual menggambarkan efek struktur geologi yang lebih dangkal, anomali tersebut diperoleh dengan pengurangan anomali gaya berat regional terhadap anomali gaya berat (Gambar 6). Anomali gayaberat residual daerah penelitian berkisar antara $-8,5 \mathrm{mgal}$ dan 5,0 mgal, memperlihatkan beberapa bulatan anomali positip dan negatip. Bulatan anomali positip diperkirakan sebagai refleksi dari batuan dengan rapat massa yang lebih tinggi dari Komplek Malihan Pemali yang diperkirakan lebih dekat kepermukaan. Seperti telah dijelaskan pada pembahasan anomali Bouguer di mana anomali rendah mendominasi pelamparan batuan terobosan Granit Klabat, maka dapat diperkirakan bahwa anomali negatip pada anomali sisa merupakan pengaruh batuan terobosan Granit Klabat tersebut. Adanya landaian kontur yang cukup rapat antara kelompok anomali negatip dan anomali positip, ditafsirkan sebagai batas antara batuan Komplek Malihan Pemali dengan batuan terobosan Granit Klabat dan diduga berupa kontak sesar, maka daerah kontak sesar ini akan potensial endapan timah sekunder karena batuan terobosan (Granit Klabat) yang diperkirakan sebagai sumber terdapatnya endapan timah akan lebih mudah mengalami penghancuran dan pelapukan pada daerah kontak sesar tersebut.

\section{Penafsiran Kuantitatif}

Untuk mengetahui struktur bawah permukaan di daerah penelitian dilakukan penafsiran dengan cara pemodelan, mempergunakan Program Gravmag pada anomali sisa (Gambar 6). Penarikan penampang pemodelan dibuat berdasarkan pertimbangan kondisi geologi dan nilai kontur anomali yang dianggap menarik pada lintasan yang akan dilakukan pemodelan.

\section{Penampang ABC}

Penampang ini di tarik sepanjang $55,0 \mathrm{~km}$ (Gambar 6 dan 7). Memotong anomali sisa dengan nilai antara - 4,5 sampai + 5,0 mgal (Gambar 7) memperlihatkan kurva berbentuk undak dan cekungan anomali. Di permukaan, batuan yang tersingkap pada penampang ini terdiri

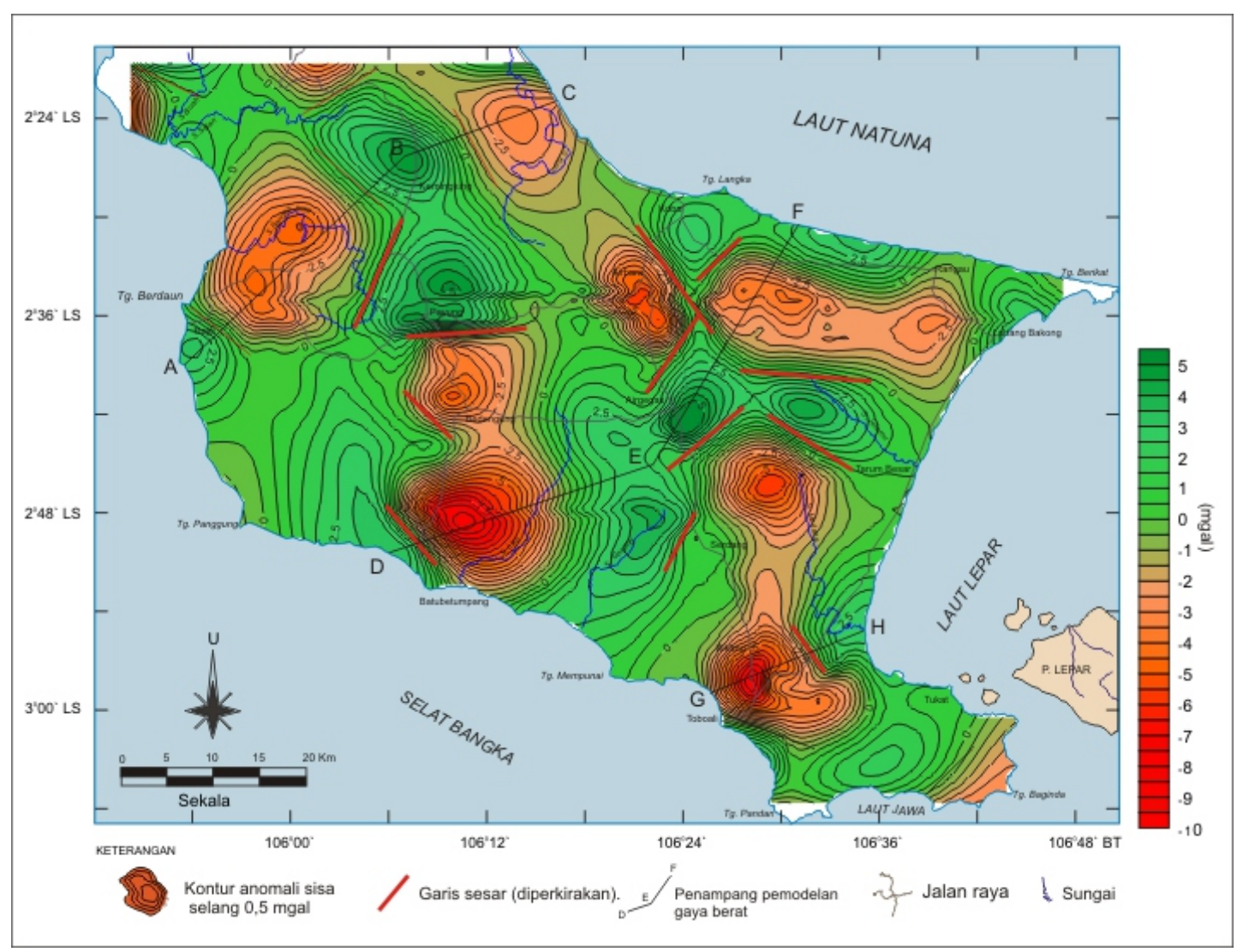

Gambar 6. Peta kontur anomali gayaberat residual daerah Bangka selatan. 
dari batuan Formasi Tanjunggenting $\left(T_{R} t\right)$, Granit Klabat, ( $\mathrm{PT}_{\mathrm{R}} \mathrm{Jkg}$ ) dan Aluvium (Margono, 1995).

Dengan memasukkan nilai rapat massa $(\rho)=2,50 \mathrm{gr} / \mathrm{cc}$ untuk Formasi Tanjunggenting, Granit Klabat $\rho=2,58 \mathrm{gr} / \mathrm{cc}$ sedangkan untuk aluvium karena dianggap tipis pengaruhnya dapat diabaikan. Hasil pemodelan memperlihatkan Formasi Tanjunggenting mempunyai ketebalan mencapai $1500 \mathrm{~m}$, dialasi oleh batuan dengan rapat massa $\rho=2,69 \mathrm{gr} / \mathrm{cc}$ yang ditafsirkan sebagai batuan Komplek Malihan Pemali dan diperkirakan sebagai batuan dasar di daerah ini. Selanjutnya Komplek Malihan Pemali dan Formasi Tanjung Genting ini di terobos oleh batuan Granit Klabat yang tersingkap di sekitar Km 4 dan $\mathrm{Km} 14$ pada gambar 9. Kontak antara batuan Granit Klabat dan Batuan Komplek Malihan Pemali, Formasi Tanjunggenting ditafsirkan sebagai kontak sesar dan diharapkan daerah yang prospek akan endapan timah sekunder.

\section{Penampang DEF}

Penampang ini ditarik sepanjang 63,0 km (Gambar 6 dan 8) memotong nilai anomali sisa antara $-8,0$ sampai $+5,0$ mgal (Gambar 8), membentuk undak dan cekungan anomali. Dipermukaan, penampang ini didominasi oleh batuan terobosan Granit Klabat, di bagian ujung penampang ditempati batuan dari Formasi Ranggam (Margono drr. 1995).

Hasil pemodelan pada penampang DEF memperlihatkan batuan dengan rapat massa 2,69 gr/cc yang ditafsirkan sebagai Komplek Malihan Pemali bertindak sebagai batuan dasar. Adanya anomali mencapai 8.0 mgal membentuk cekungan anomali di $\mathrm{Km} 5$ sampai $\mathrm{Km} 15$ pada penampang DEF disebabkan oleh terobosan batuan berapat massa 2,58 gr/cc yang ditafsirkan sebagai Granit Klabat. Bentuk undak anomali di sekitar $\mathrm{Km} 25$ sampai $\mathrm{Km} 58$ yang mencapai 5,0 mgal ternyata diakibatkan oleh pengaruh batuan Komplek Malihan Pemali yang lebih dekat kepermukan dan ditutupi oleh batuan Granit Klabat. Adanya penurunan anomali di lokasi ini (titik E pada kurva) diakibatkan adanya bentuk undulasi yang diperkirakan sebagai akibat adanya sesar pada batuan Komplek Malihan Pemali.

\section{Penampang GH}

Penampang ini di tarik sepanjang 19,0 km (Gambar 6 dan 9), memotong nilai anomali gaya berat sisa antara - 8,0 sampai 3,0 mgal (Gambar 9) membentuk seolaholah cekungan anomali. Di permukaan, penampang ditempati batuan dari Formasi Tanjunggenting, Formasi Ranggam, Granit Klabat dan Aluvium (Margono drr. 1995).

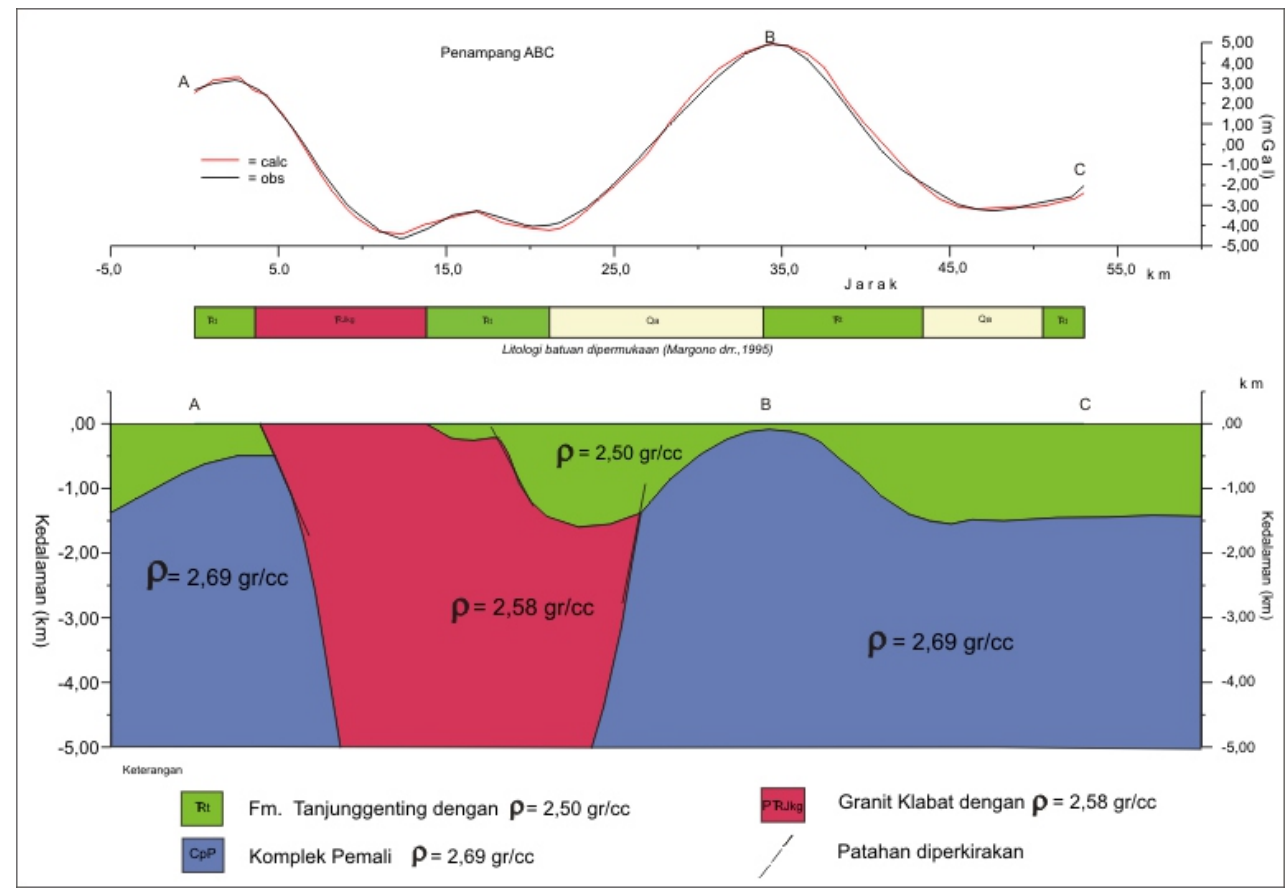

Gambar 7. Peta kontur anomali gayaberat residual daerah Bangka selatan. 


\section{MAKALAH ILMIAH}

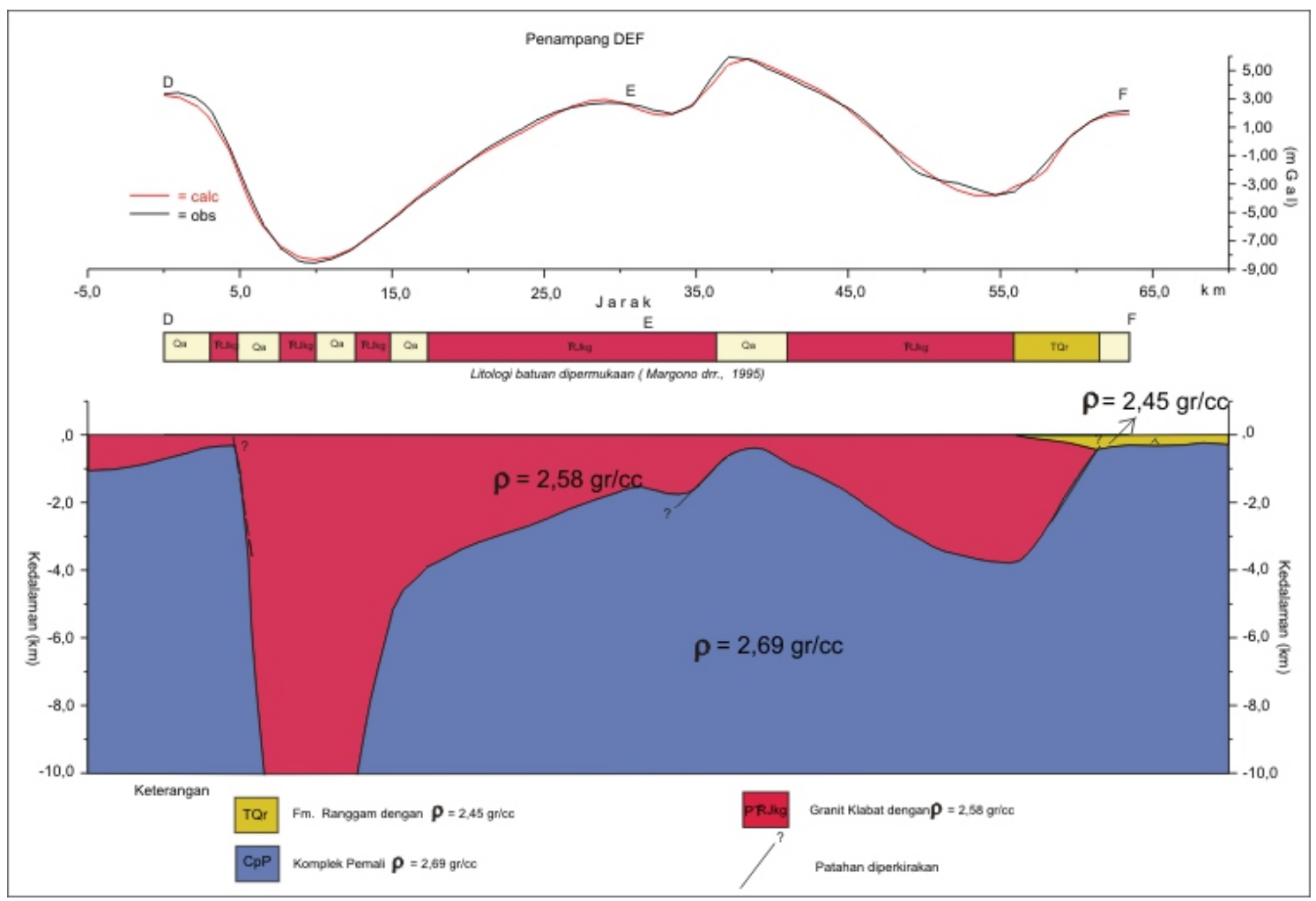

Gambar 8. Model Geologi bawah permukaan pada penampang D-E-F.

Hasil pemodelan memperlihatkan Formasi Tanjunggenting dengan rapat masa $2,50 \mathrm{gr} / \mathrm{cc}$, yang tersingkap antara $\mathrm{Km} 9$ sampai Km 15 mencapai ketebalan 1000 m di sekitar $\mathrm{Km} \mathrm{9,} \mathrm{dan} \mathrm{menipis} \mathrm{(membaji)}$ kearah ujung penampang mencapai ketebalan sekitar $200 \mathrm{~m}$ di $\mathrm{Km} 15$. Sedangkan lapisan dengan rapat massa 2,40 gr/cc terdapat antara Km 15 dan ujung penampang yang ditafsirkan sebagai Formasi Ranggam dengan ketebalannya kurang dari $200 \mathrm{~m}$. Anomali mencapai - 8,0 mgal membentuk cekungan anomali dengan sumbunya di sekitar $\mathrm{Km} 4$ dan $\mathrm{Km} 6$ diperkirakan akibat pengaruh medan gaya berat dengan rapat massa $2,58 \mathrm{gr} / \mathrm{cc}$ yang ditafsirkan sebagai batuan terobosan granit Klabat sesuai yang tersingkap di permukaan. Batuan ini menerobos batuan Komplek Malihan Pemali yang diperkirakan sebagai batuan dasar di daerah tersebut.

Dari hasil pemodelan yang dilakukan pada tiga lintasan penampang yang telah dijelaskan di atas, kontak batuan antara Formasi Tanjunggenting, Komplek Pemali dan Granit Klabat diperkirakan sebagian besar sebagai kontak sesar, sehingga daerah kontak batuan ini merupakan daerah yang prospek untuk terdapatnya jebakan endapan timah.

\section{KESIMPULAN}

Pola anomali gayaberat daerah Bangka Selatan menunjukkan deliniasi sebaran batuan granit dengan nilai anomali lebih kecil dari $29 \mathrm{mGal}$, dengan arah barat timur. Sedangkan pola anomali gayaberat residual menunjukkan penyebaran batuan granit lebih merata di bagian selatannya, yang dicerminkan oleh nilai nilai anomali lebih kecil dari $0 \mathrm{mGal}$. Zona sesar sebagai kontak struktur menempati kontur anomali gayaberat residual terletak pada kaki punggungan anomali dengan nilai kontur 1 atau $2 \mathrm{mGal}$ dan searah dengan cekungan anomali residual.

Pola struktur geologi di Bangka Selatan dicerminkan oleh kelurusan anomali yang yang berarah berarah baratdaya -timurlaut dan berarah baratlaut-tenggara. Pola struktur tersebut merupakan refleksi kontak struktur regional dan terobosan batuan Komplek Pemali.

Dengan analisis data gayaberat melalui pemodelan geologi bawah 


\section{MAKALAH ILMIAH}

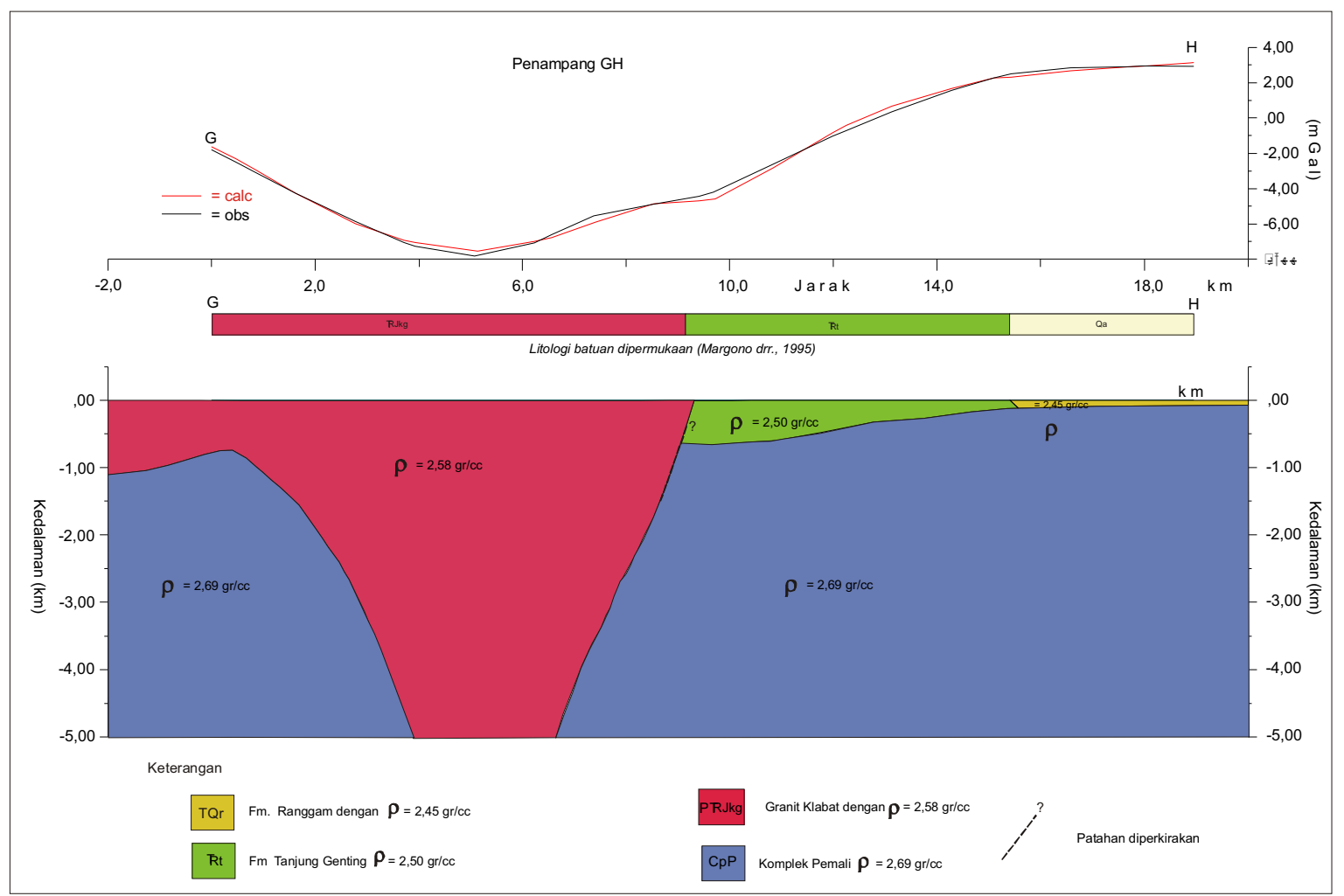

Gambar 9. Model geologi bawah permukaan pada penmapang G-H.

permukaan dan pola anomali gayaberat yang berhubungan dengan anomali rendah dan zona strukturnya, hubungan antara batuan Komplek Malihan Pemali, Formasi Tanjunggenting dengan batuan terobosan Granit ditafsirkan sebagai kontak sesar.

Analisis qualitatif pada penampang anomali gayaberat residual memperlihatkan rapat massa $2,69 \mathrm{gr} / \mathrm{cc}$ ditafsirkan sebagai Komplek Pemali merupakan batuan yang mengalasi daerah tersebut. Nilai rapat massa 2,58 gr/cc merupakan batuan terobosan yang ditafsirkan sebagai Granit Klabat. Komplek Pemali yang diterobos oleh batuan Granit Klabat, membentuk kontak struktur pada zona lemah sesar dan hancuran, diduga sebagai daerah potensi endapan timah di Bangka Selatan.

\section{UCAPAN TERIMAKASIH}

Penulis mengucapkan terima kasih kepada Kepala Pusat Survei Geologi dan Kepala Pusat Sumber Daya Geologi beserta staf, yang telah memberikan kesempatan untuk melakukan penulisan karya ilmiah di daerah Pulau Bangka bagian Selatan. Pada kesempatan ini penulis juga mengucapkan terimakasih kepada tim Editor dan Dewan Redaksi yang telah mengoreksi dan menerbitkan karya ilmiah ini.

\section{DAFTAR PUSTAKA}

Djumhana, D., 1995. Beberapa Aspek Petrologi Batuan Granitik di Daerah Bagian Barat P. Bangka, Kolokium Hasil Pemetaan dan Penelitian Puslitbang Geologi 1992/1993, Publikasi Khusus No. 16, 101-117, Pusat Penelitian dan Pengembangan Geologi.

Chappel, B.W., WhiteA.J.R., 1974. Two Contrasting Granite Types, Pasific Geology 8, 173-174.

Gafoer, S., Amin, T.C., Setyogroho, B., 1992. Peta Geologi Indonesia, Lembar Palembang, sekala $1: 1000.000$, Pusat Penelitian dan Pengembangan Geologi (PPPG) Bandung.

Hutchison, R.W., 1980. Massive base metal sulphide deposits as guides to tectonicevolution. In: Strangeway D.W (ed.), The continental crust and its mineral deposits. Geological Association of Canada, Special Peper 20. 659-684. 


\section{MAKALAH ILMIAH}

Ishihara, S., 1980. Granite and Sn-W deposits of Peninsular Thailand, Mining Geology Spesial Issue. No. 8, 223-241.

Lehmann, B., 1990. Metallogony of tin lecture Notes in Earth Sciences, 32. Springer-Verlag, Berlin.

Margono, U., Supandjono. R.J.B dan Partoyo,E., 1995. Peta Geologi Bangka Selatan, Sumatera, sekala $1: 250.000$, Pusat Penelitian dan Pengembangan Geologi (PPPG) Bandung.

Marzuki, S., Manurung, A., Suharyono, S., Mirnanda, E. dan Walker, A., 1990. Peta Anomali Bouguer Lembar Bangka selatan, Sumatera, sekala 1: 250.000, Pusat Penelitian dan Pengembangan Geologi (PPPG) Bandung.

Simamora, W.H., 2007. Penafsiran Struktur Bawah Permukaan Bangka Utara Berdasarkan Anomali Gaya berat, Pusat Survei Geologi, Jurnal Sumber Daya Geologi Vol. XVII No. 3, 163-177. 